\title{
EFEKTIVITAS PEMBATASAN USIA PERKAWINAN BERDASARKAN UNDANG-UNDANG NOMOR 1 TAHUN 1974 TENTANG PERKAWINAN
}

\author{
Musyarrofa Rahmawati, Hanif Nur Widhiyanti, Warkum Sumitro \\ Prodi Magister Kenotariatan Universitas Brawijaya \\ Jl. MT. Haryono Nomor 169 Malang \\ Email : rofarahmawati@gmail.com
}

\begin{abstract}
This article described the effectiveness of limiting the age of marriage based on Act No.1 of 1974 about marriage. The method used empirical juridical or sociological juridical in Probolinggo Regency. The informants in this study were principles, teachers of Counseling Guidance, Heads of Religious Affairs Offices in Probolinggo District, and dropout students who underage marriages. The results of the study showed that restrictions on marriage age have not been effective in the implementation domain. This fact showed from a large number of underage marriages conducted among the public. Factors causing marriage under age were: (1) community culture, matchmaking, (2) relationships that were too close in dating, (3) pregnancy outside marriage.
\end{abstract}

Keywords: early marriage, restrictions on marriage age

\begin{abstract}
Abstrak: Artikel ini mendeskripsikanefektifitas pembatasan usia perkawinan berdasarkan UndangUndang No.1 Tahun 1974. Metode yang digunakan kajian ini yuridis empiris atau yuridis sosiologis di wilayah Kabupaten Probolinggo. Informan dalam kajian ini adalah kepala sekolah, guru Bimbingan Konseling, Kepala Kantor Urusan Agama di Kabupaten Probolinggo, dan siswa putus sekolah yang melakukan pernikahan di bawah umur. Hasil kajian menunjukkan bahwa pembatasan usia perkawinan belum efektif dalam ranah implementatif. Hal tersebut dapat dilihat dari banyaknya angka perkawinan di bawah umur yang dilakukan di kalangan masyarakat umum. Faktor penyebab perkawinan di bawah usia adalah: (1) budaya masyarakat, perjodohan, (2) hubungan yang terlalu dekat dalam berpacaran, (3) hamil di luar kawin.
\end{abstract}

Kata Kunci: Perkawinan di bawah umur, Pembatasan usia perkawinan

Studi yang dilakukan United Nations Children's Fund (UNICEF), fenomena perkawinan di bawah umur (early marriage) masih sering dijumpai pada masyarakat di Timur Tengah dan Asia Selatan dan pada beberapa kelompok masyarakat di Sub Sahara Afrika. Di Asia Selatan terdapat 9,7 juta anak perempuan atau $48 \%$ menikah pada umur dibawah usia 18 tahun, Afrika sebesar 42\% dan Amerika Latin sebesar 29\%, (Juspin, 2014).Di Indonesia, angka statistik perkawinan di bawah umur dengan pengantin berumur di bawah usia 16 tahun secara nasional mencapai lebih dari seperempat, bahkan di beberapa daerah, sepertiga dari pernikahan yang terjadi tepatnya di Jawa Timur 39,43\%, Kalimantan Selatan 35,480 \%, Jambi 30,63\% dan Jawa Barat $36 \%$.
Dari data di atas, Jawa Timur memiliki angka tertinggi dalam pelaksanaan perkawinan di bawah umur. Termasuk yang terjadi di Kabupaten Probolinggo, masih banyak dijumpai fenomena ini. Salah satunya sebagai contoh yang terjadi di SMA ISLAM TAJUNG SARI, Kecamatan Tongas, Kabupaten Probolinggo. Setiap tahun, sekolah ini hanya akan meluluskan 13 sampai dengan 15 siswa saja. Padahal diawal tahun ajaran setiap angkatan, jumlah peserta didiknya adalah 30 sampai dengan 50 siswa. Artinya, selama proses pembelajaran berlangsung dari kelas 10 sampai dengan kelas 12, lebih dari $50 \%$ siswa putus sekolah karena menikah sebelum menyelesaikan masa pendidikan. 
Padahal dalam Instruksi Mendagri Nomor 27 Tahun 1983 tentang Usia Perkawinan dalam Rangka Mendukung Program Kependudukan dan Keluarga Berencana menyebutkan bahwa perkawinan usia muda adalah perkawinan yang dilakukan pada usia di bawah 20 tahun bagi wanita dan di bawah 25 tahun bagi pria. Undang-Undang Nomor 1 Tahun 1974 Tentang Perkawinan mempunyai hubungan erat dengan masalah kependudukan. Adanya pembatasan umur perkawinan baik bagi pria maupun wanita diharapkan laju angka kelahiran dapat ditekan seminimal mungkin. Dengan demikian, program Keluarga Berencana Nasional dapat berjalan seiring dan sejalan dengan Undang-undang ini, (Dirjen Binmashaji, 2003).

Patut diketahui, tujuan ditentukannya batas usia minimal pada Pasal 7 ayat (1) UndangUndang Perkawinan dan dispensasi pada Pasal 7 ayat (2) Undang-Undang Perkawinan tidak terlepas dari benturan kepentingan beberapa kelompok pada saat perumusan Undang-undang Perkawinan itu sendiri. Pada tahun 1973, gelombang protes oleh umat Islam atas Rancangan Undang-undang Perkawinan pada saat itu sangat keras yang juga dimotori oleh beberapa ulama besar. Penolakan ini terjadi karena Rancangan Undang-undang perkawinan pada saat itu tidak merepresentasikan nilai-nilai Islam dan bahkan mengenyampingkan nilai-nilai tersebut. Adapun yang menjadi salah satu poin perdebatan adalah mengenai usia batas minimal melakukan perkawinan pada Rancangan Undang-undang Perkawinan, yakni 18 tahun bagi wanita dan 21 tahun bagi pria. Dari hasil perundingan yang dilakukan oleh pemerintah dan perwakilan ulama pada saat itu, dicapai kesepakatan untuk mengubah batasan umur tersebut menjadi 16 tahun untuk wanita dan 19 tahun untuk pria, seperti yang terdapat pada Pasal 7 ayat (1) Undang-undang Perkawinan. Penetapan usia 16 dan 19 tahun ini merupakan jalan tengah antara dua pihak, karena pada ilmu Islam tidak dikenal adanya batasan usia minimal untuk melangsungkan perkawinan dan hanya didasarkan pada keadaan biologis, seperti akhil baligh (Antarini, 2017).

Pada dasarnya penetapan batas usia perkawinan memang bertujuan demi kemaslahatan dan kebaikan terutama bagi calon mempelai. Dalam Penjelasan Umum UndangUndang Nomor 1 Tahun 1974 Tentang Perkawinan Nomor 4 Huruf (d) dijelaskan bahwa prinsip calon mempelai harus masak jiwa raganya dimaksudkan agar dapat mewujudkan tujuan perkawinan secara baik tanpa berakhir pada perceraian dan mendapat keturunan yang baik dan sehat. Pembatasan usia perkawinan juga dilakukan dengan maksud meningkatkan kualitas Sumber Daya Manusia Indonesia. Dengan pembatasan usia perkawinan, diharapkan anak Indonesia bisa mendapatkan masa pendidikan yang lebih panjang sehingga kelak mampu meningkatkan kualitas sumber daya manusia Indonesia. Meskipun demikian, Undang-undang tetap memberikan peluang melakukan perkawinan di bawah umur. Artinya, Undang-undang Perkawinan memberikan jalan keluar berupa dispensasi kawin melalui pengadilan. Berdasarkan Peraturan Menteri Agama Nomor 3 Tahun 1975 bahwa Dispensasi Pengadilan Agama ialah penetapan yang berupa dispensasi untuk calon suami yang belum mencapai umur 19 tahun dan atau calon istri yang belum berumur 16 tahun yang dikeluarkan oleh Pengadilan Agama. Namun demikian, dalam Undang-undang Sistem Pendidikan Nasional, Undang-undang Nomor 20 Tahun 2003, sebenarnya tidak diberikan batasan secara pasti bahwa anak yang hamil dan menikah tidak dapat melanjutkan pendidikannya (Khaqam, 2015).Tapi hampir keseluruhan diantara mereka tidak punya kesempatan untuk mendapatkan pendidikan lebih lanjut. Oleh karena itu, tulisan ini akan mengkaji tentang"Pelaksanaan Ketentuan Pembatasan Usia Perkawinan Pada Siswi Sekolah Menengah Atas Di Kabupaten Probolinggo".

Ketika ingin mengetahui sejauh mana efektifitas dari hukum, maka kita pertama-tama harus mengukur sejauh mana aturan hukum itu ditaati atau tidak ditaati, tentu saja, jika suatu aturan hukum ditaati oleh sebagian besar target yang menjadi sasaran ketaatannya, kita mengatakan bahwa aturan hukum yang bersangkutan adalah efektif. Suatu aturan hukum harus keadaan valid terlebih dahulu baru diketahui apakah aturan tersebut berjalan efektif. Agar hukum tersebut dapat menjadi valid, hukum tersebut haruslah dapat diterima oleh masyarakat. Demikian sebaliknya, bahwa agar dapat diberlakukan terhadap masyrakat, maka suatu kaedah hukum haruslah merupakan hukum valid atau legitemate. berlaku efektif berarti bahwa orang benar-benar berbuat sesuai dengan norma-norma hukum sebagaimana mereka harus mengikat, bahwa norma-norma itu benar-benar dapat diterapkan dan dipatuhi, (Munir, 2013). 
Menurut Soerjono Soekanto, faktor-faktor yang mempengaruhi efektivitas suatu undangundang ada empat, yaitu : (a) hukumnya sendiri, (b) penegak hukum, (c) sarana dan fasilitas, (d) masyarakat dan kebudayaannya. Teori Perlindungan Hukum bagi anak yang dikemukakanPhilipus (1991), menitikberatkan kepada perlindungan hukum dibidang hak asasi anak. Teori perlindungan anak dapat diartikan sebagai upaya perlindungan hukum terhadap berbagai kebebasan dan hak asasi anak (fundamental rights and freedoms of children) serta berbagai kepentingan yang berhubungan dengan kesejahteraan anak (Nawawi, 1998). Perlindungan anak secara umum adalah suatu tata kehidupan dan penghidupan anak yang dapat menjamin pertumbuhan dan perkembangannya dengan wajar, baik secara rohani, jasmani maupun sosial (Hadisuprapto, 1996).

\section{METODE}

Kajian dalam tulisan ini studi empiris atau yuridis sosiologis. Kajian empiris adalah suatu metode kajian hukum yang bertujuan untuk melihat hukum dan bekerjanya hukum dalam masyarakat. Pengumpulan data diperoleh dari fakta-fakta yang ada di dalam suatu masyarakat, badan hukum atau badan pemerintah(Iqbal, 2002).Pendekatanyuridis sosiologis yang dipergunakan untuk melihat kesenjangan antara hukum yang berlaku dengan praktek di lapangan tentang pelaksanaan ketentuan pembatasan usia perkawinan pada siswa Sekolah Menengah Atas di Kabupaten Probolinggo.

Populasi dalam penelitian ini adalah semua pihak yang terkait dengan pernikahan di bawah umur, meliputi semua siswa yang putus sekolah karena melakukan pernikahan di bawah umur dan tidak melanjutkan sekolah, Kepala Sekolah dan guru Bimbingan Konseling, Ketua Pengadilan Agama, serta Kepala Kantor Urusan Agama di Kabupaten Probolinggo yang melakukan pencatatan pernikahan mempelai di bawah umur. Informan dalamkajian ini adalah Kepala Sekolah dan guru, Kepala Kantor Urusan Agama di Kabupaten Probolinggo, serta siswa putus sekolah yang melakukan pernikahan di bawah umur.

\section{HASIL DAN PEMBAHASAN}

Angka perkawinan di bawah umur di Kabupaten Probolinggo cukup tinggi, dari total
4.017 pernikahan yang tercatat hingga akhir 2016 lalu, 1.811 pernikahan di antaranya $(45,08 \%)$ masuk kategori pernikahan di bawah umur.Pernikahan di bawah umur yang tertinggi terdapat di Kecamatan Krucil. Dari total 245 pernikahan, 152 pernikahan (62\%) masuk kategori pernikahan di bawah umur. Berikutnya di Kecamatan Tiris, dari total 358 pernikahan yang dilangsungkan selama tahun 2016, 177 pernikahan (49 \%) masuk kategori pernikahan di bawah umur.

Pernikahan di bawah umur yang dilakukan di Kabupaten Probolinggo juga tidak semuanya dilakukan melalui prosedur penetapan pengadilan. Data dari Pengadilan Agama Kabupaten Probolinggo, penetapan dispensasi perkawinan selama kurun waktu 2016 hanya sejumlah 74. Dari 1.811 pernikahan di bawah umur, hanya 74 pernikahan yang didahului dengan proses penetapan pengadilan. Dengan demikian, bisa dikatakan sebagian besar dilakukan tanpa melalui proses penetapan pengadilan terlebih dahulu. Contohnya yang terjadi pada sebagian siswi SMA Tajung Sari, rata-rata perkawinan dibawah umur yang mereka lakukan tidak melalui prosedur penetapan pengadilan. Penyimpangan yang dilakukan adalah dengan melakukan penambahan umur pada umur asli calon mempelai pria dan wanita.

Berkaitan dengan kondisi pernikahan di bawah umur yang cukup tinggi tersebut, Hakim Pengadilan Agama Kabupaten Probolinggo menyampaikan bahwa Pengadilan Agama tidak mengetahui kalau terdapat pernikahan di bawah umur dalam jumlah yang sangat tinggi di Kabupaten Probolinggo. Permohonan dispensasi kawin selalu ada di setiap bulannya, bahkan pada tahun 2016 terdapat 74 permohonan dispensasi kawin. Permohonan dispensasi kawin sebagian besar diterima, hanya sebagian kecil saja yang ditolak.Permohonan dispensasi kawin yang ditolak rata-rata tetap melangsungkan pernikahan di bawah tangan. Beberapa tahun berikutnya pasangan tersebut meminta isbath nikah.

Beberapa alasan diberikannya dispensasi kawin antara lain karena; (1)kedua calon mempelai sudah berpacaran dengan sangat erat sehingga orang tua khawatir terjadi hal-hal yang tidak diinginkan di kemudian hari, (2) terjadi kehamilan di luar pernikahan, (3) perjodohan oleh orang tua dalam usia calon mempelai yang masih sangat muda. Pernikahan di bawah tangan di Kabupaten Probolinggo sangat lumrah terjadi, biasanya saat ditunangkan pasangan juga langsung 
dinikahkan (di sirri). Terlihat dengan adanya program isbath massal yang diadakan oleh Pemerintah Kabupaten Probolinggo setiap tahun. Peserta isbath massal sebagian besar juga ternyata pasangan yang ketika menikah masih di bawah umur. Selama tahun 2015 peserta isbath massal sejumlah 578 pasangan. Sementara pada tahun 2016 sejumlah 502 pasangan memohon isbath nikah. Dari pemohon isbath nikah tersebut, sebagian besar adalah pasangan usia muda.Sebelum menerima permohonan dispensasi perkawinan, majelis hakim biasanya memberikan pembinaan dan pengarahan tentang bahaya menikah di usia muda.Sebagian kecil dari pasangan pernikahan di bawah umur itu berakhir dengan perceraian.

Berdasarkan catatan di Badan Pusat Statistik Kecamatan Krucil dan Tirismenempati urutan pertama dan kedua dalam angka pernikahan di bawah umur.Angka perkawinan di bawah umur cukup tinggi dan setiap bulan selalu ada permohonan dispensasi perkawinana. Pihak pengadilan menyatakan tidak mengetahui terhadap adanya praktek perkawinan di bawah umur. Cara yang digunakan untuk melangsungkan perkawinan anak di bawah umur adalah dengan memanipulasi usia, yaitu dengan menambah usianya sehingga dapat mendapatkan surat ijin untuk melangsungkan perkawinan. Hal tersebut dapat dilihat dari kasus penolakan yang dilakukan oleh KUA karena usia belum memenuhi dan beberapa hari kemudian kembali ke KUA dengan usia yang berbeda. Hal tersebut seringkali terjadi dan secara prosedur KUA tidak memiliki wewenang untuk mengecek data usia calon mempelai. Sepanjang sudah memenuhi ketentuan yang ditetapkan, maka KUA tetap akan memproses pada tahap pencatatan perkawinan.

Perkawinan di bawah umur yang melibatkan anak-anak yang masih sekolah juga menjadi urusan sekolah. Sekolah pada umumnya selalu memotivasi siswanya agar tetap melanjutkan sekolah dengan segala kondisi yang ada. Keputusan siswa untuk berhenti sekolah murni berada di tangan siswa itu sendiri dan orang tuanya. Selama ini, ketika siswa memutuskan menikah, tidak pernah ada yang melanjutkan pendidikannya. Padahal, sekolah tidak melarang pada siswa yang menikah karena perjodohan untuk terus belajar di sekolah tersebut. Kecuali siswa yang menikah karena melakukan perbuatan asusila, maka sekolah dengan terpaksa mengeluarkan siswa tersebut dan menganjurkan siswa untuk melanjutkan pendidikan melalui kejar paket.

Sebagian besar siswa tidak merasa terpaksa ketika dijodohkan orang tuanya. Menikah muda atau bertunangan menjadi trend di kalangan siswi yang juga santriwati (sekolah yang berbasis pondok pesantren). Mereka sering saling bercerita betapa menyenangkannya kegiatan yang dilakukan dengan pasangan masing-masing. Bahkan cenderung meledek teman-temannya yang belum memiliki tunangan. Pada siswi atau santriwati yang sudah memiliki tunangan, motivasi belajarnya sangat rendah. Mereka beranggapan tidak berguna bersungguh-sungguh belajar, karena pada akhirnya hanya akan mengurus rumah tangga saja.

Semua pihak wajib mengusahakan pendidikan untuk setiap warga negara, terutama untuk pendidikan anak Indonesia yang tentu saja merupakan generasi penerus bangsa. Semua pihak yang terkait telah berusaha sungguh-sungguh memperjuangkannya, kecuali orang tua dengan pendidikan yang rendah tentunya akan menganggap remeh pentingnya pendidikan bagi putra-putrinya. Untuk itu diperlukan perjuangan keras dari pemerintah untuk membentuk kesadaran komunal bagi warga masyarakat Kabupaten Probolinggo ini.

Tujuan pembatasan usia perkawinan adalah untuk memberikan manfaat selain kepada kedua mempelai, juga untuk seluruh anggota keluarga besar dan masyarakat. Di masyarakat pedesaan, perkawinan di bawah umur terjadi terutama pada golongan ekonomi menengah kebawah yang lebih merupakan bentuk sosial pada pembagian peran dan tanggung jawab dari keluarga perempuan pada suami. Di masyarakat perkotaan, perkawinan di bawah umur umumnya terjadi karena terjadi kehamilan di luar pernikahan akibat salah pergaulan oleh remaja (Wantjik, 2004).Dengan kata lain, bahaya melakukan pernikahan di bawah umur tidak difahami oleh masyarakat. Para orang tua di Kabupaten Probolinggo masih dengan mudah menikahkan anak-anak mereka yang masih di bawah umur dengan berbagai alasan. Kalau di wilayah perdesaan, ada anggapan bahwa menikah di atas usia 20 tahun bagi perempuan akan dianggap sebagai perawan tua. Sedangkan di wilayah yang dekat dengan perkotaan biasanya kesadaran akan pendidikan anak sudah mulai tinggi, akan tetapi mereka menikahkan anak mereka yang masih di bawah umur dikarenakan anaknya telah salah pergaulan dan hamil sebelum 
melakukan pernikahan. Di kabupaten Probolinggo, sebagaimana dijelaskan sebelumnya juga terjadi fenomena serupa. Artinya, fenomena perkawinan di bawah umur ini menunjukkan bahwa batasan usia untuk menikah dan prosedur permohonan dispensasi yang ditetapkan oleh Undang-Undang Perkawinan perlu diuji lagi efektivitasnya. Soerjono Soekanto menyatakan bahwa efektivitas pelaksanaan ketentuan dipengaruhi oleh substansi peraturan, penegak hukum, sarana dan fasilitas, serta masyarakat dan budaya.

Dalam batasan usia menikah 16 tahun bagi perempuan menurut Undang-Undang Perkawinan perlu dikaji efektivitas dan korelasinya dengan kebutuhan anak akan pendidikan saat ini. Karena menurut usia belajar dalam lingkup pendidikan formal Indonesia saat ini, usia 16 tahun adalah usia ketika seorang siswa masih duduk di kelas XI (sebelas) pada sekolah menengah atas. Sebagai contoh adalah SMA Tajung Sari berlokasi di wilayah perdesaan di Kabupaten Probolinggo. Sebagaimana dijelaskan sebelumnya, kesadaran untuk memiliki pendidikan yang layak pada masyarakatnya masih rendah. Dengan batasan usia menikah 16 tahun dalam Undang-undang Perkawinan, maka siswi kelas XII (dua belas) sekolah tersebut tidak dapat dikatakan menikah di bawah umur apabila melangsungkan perkawinan. Namun, siswi yang bersangkutan tidak dapat menyelesaikan hak pendidikannya. Kenyataan di lapangan, dengan batasan usia menikah saat ini saja, banyak siswi yang menikah ketika masih di tahun pertama masa pendidikan mereka di SMA Tajung Sari.

Sebagaimana dijelaskan sebelumnya, sebagian besar perkawinan di bawah umur dilaksanakan tanpa proses penetapan pengadilan terlebih dahulu. Artinya, ada proses pemalsuan data usia calon mempelai yang dilakukan oleh aparat negara. Kalaupun melalui proses penetapan pengadilan, alasan hakim memberikan dispensasi perkawinan pun sangat mudah. Dalam banyak kasus, sangat jarang atau bahkan tidak pernah ditemui hakim dalam menerima atau menolak permohonan dispensasi, mempertimbangkan halhal yang jauh lebih besar dari sekadar formalitas dan hubungan kedua mempelai, seperti: akibat perkawinan bagi calon mempelai di bawah umur, konsekuensi terhadap pendidikan, dan hak-hak anak lainnya. Termasuk dispensasi perkawinan yang dikeluarkan oleh hakim Pengadilan Agama Kabupaten Probolinggo.
Faktor sarana atau fasilitas pendukung mencakup perangkat lunak dan perangkat keras, salah satu contoh perangkat lunak adalah pendidikan. Pendidikan orang tua yang rendah juga menjadi faktor pendukung banyaknya pernikahan di bawah umur yang terjadi pada siswi SMA di Kabupaten Probolinggo. Masalah perangkat keras dalam hal ini adalah sarana fisik yang berfungsi sebagai faktor pendukung.

Masyarakat Kabupaten Probolinggo masih memiliki anggapan bahwa perempuan yang menikah di usia di atas 20 tahun adalah perawan tua atau menurut bahasa mereka disebut dengan sangkal. Sangkal adalah kondisi dimana seorang gadis yang selalu di tolak oleh banyak jejaka. Sehingga orang tua yang memiliki anak gadis cenderung segera ingin menikahkan anak-anak mereka. Bahkan, ketika anak gadis mereka sudah berada di jenjang akhir pendidikan Sekolah Menengah Pertama, mereka sudah menjodohkannya. Perjodohan ini disebut dengan pertunangan atau menurut bahasa mereka bugelan atau bekalan. Pada saat bugelan atau bekalan ini, biasanya anak gadis sudah diperkenankan menginap di rumah calon suaminya. Sebuah hal yang dianggap wajar ketika pasangan yang terikat bugelan atau bekalan ini pergi kemana-mana berdua. Sehingga, tidak jarang terjadi ketika seorang siswi baru kelas sebelas Sekolah Menengah Atas hamil oleh bugel atau bekalnya.

\section{SIMPULAN}

Pembatasan usia perkawinan dalam peraturan perundangan masih belum efektif. Angka perkawinan di bawah umur masih sangat tinggi. Alasan dilakukannnya perkawinana di bawah umur adalah budaya perjodohan sejak usia masih anak-anak, ketakutan orang tua karena anaknya berpacaran terlalu dekat, dan terjadinya kehamilan di luar pernikahan. Perkawinan tersebut ada yang dicatatkan dan tidak dicatatkan dalam administrasi resmi peraturan kenegaraan. Perkawinan yang dilakukan anak di bawah umur dapat dicatatkan karena adanya penambahan usia (dituakan) pada saat dicatatkan baik melalui prosedur hukum yang sah (peradilan) maupun tidak. Perkawinan yang tidak dicatatkan dan tetap dilangsungkan adalah perkawinan yang dilangsungkan secara sirri (sembunyisembunyi). 


\section{DAFTAR RUJUKAN}

\section{Buku-buku}

Amin, Khaqam, El-Chudrie, 2015, FiqhKeluarga: SuksesMerajutKeluarga, Kudus: ArRaudhah Press

Nawawi, Barda, Arief, 1998, Beberapa Aspek Kebijaksanaan Penegakan dan Pengembangan Hukum Pidana, Bandung: PT. Citra Aditya Bakti,

Direktorat Jenderal masyarakat Islam dan Penyelenggaraan Haji, 2003,Membina Keluarga Sakinah, Jakarta: Dirjen Binmashaji

Iqbal Hasan, 2002, Pokok-pokok Materi Metodologi Penelitian, Jakarta: Ghalia Indonesia

Munir, Fuady, 2013, Teori-teoriBesar dalam Ilmu Hukum, Jakarta: Kencana

Paulus, Hadisuprapto, 1996, Juvenile Delinquency Pemahaman Dan Penanggulangannya, Bandung: PT.Citra Aditya Bakti

Philipus, Hadjon,1991, Perlindunganhukum bagirakyat di Indonesia, Surabaya: Bina Ilmu.

Wantjik, 2004,Hukum Perkawinan Indonesia, Jakarta : Ghalia Indonesia

\section{PeraturanPerundang-Undangan :}

Undang-Undang Nomor 1 Tahun 1974 tentang Perkawinan.

Undang-Undang Nomor 23 tahun 2002 jo Undangundang Nomor 35 tahun 2014 tentang Perlindungan Anak.
Undang-Undang Nomor 20 Tahun 2003 tentang Sistem Pendidikan Nasional.

\section{Jurnal:}

JuspinLandung, RidwanThaha', A. Zulkifliabdullah, "StudiKasusKebiasaanPernikahanUsia Dini Pada Masyarakat Kecamatan Sanggalangi Kabupaten Tana Toraja” (Makassar, RantepaKab. Toraja Utara: Fakultas Kesehatan Masyarakat Universitas Hasanuddin; Jurnal MKMI, Vol 5 No.4. Oktober 2014)

\section{Internet:}

AntariniArna, SH LLM; "Sebagai Draft Keterangan Ahli Tertulis dalam Perkara Pengujian Undang-Undang No 1 tahun 1974 terntangPerkawinanPasal 7 ayat (1) danayat (2), Perkara No 74/PUU-XII/ 2014", http://www.hukumpedia.com/18coalition/problem-penyimpangan-dandispensasi-dalam-pasal-7-ayat-2-undangundang-no-1 - tahun-1974-tentangperkawinan, diakses 21 Februari 2017 padapukul 11:47

Portal PemerintahKabupatenProbolinggo, http:// www.probolinggokab.go.id/index.php? o p t i o n $=$ c o m c o n t e n t \& view $=$ article $\& i d=2806$ :angka-pernikahandini-masih-tinggi\&catid=86:pemerintahan, diakses Kamis, 2 Maret 2017, pukul 03:32 